\title{
Assessment of Sustainable Production of Stable Food Crops in Southern Darfur State, Sudan
}

\author{
Babikir A Mohamed ${ }^{1}$, Eltighani M Elamin ${ }^{1 *}$, Abd Elaziz $^{1}$ and A Hashim Alobied ${ }^{2}$ \\ ${ }^{1}$ Agricultural Economic \& Policy Research Center (AEPRC, Khartoum North), Sudan \\ ${ }^{2}$ Development Studies and Research Institute (DSRI, Khartoum), Sudan \\ Received: 眥 November 10, 2018; Published: 眥 November 15, 2018 \\ *Corresponding author: Eltighani M Elamin, Agricultural Economic \& Policy Research Center (AEPRC, Khartoum North), Sudan
}

\begin{abstract}
The main purpose of this study is to assess the sustainability of production of millet and sorghum, the main stable food crops in traditional rain fed areas in Southern Darfur State (SDS), and explore the potential resources, capabilities and constraints of production and the possibility of regional trade between SDS and the other States of the country. The results of the study revealed that the main factors constraining production in SDS are farm access insecurity which represents 30\%, ineffective control of pests and diseases $20 \%$, poor genetic stock $20 \%$, inadequate amount of rainfall $14 \%$ and low fertility of Qoz and Atmur soils $6 \%$, lack of extension service $6 \%$ and financial lack of ability $4 \%$. The small producers have limited access to credit and research released technological knowledge. Total area planted per household was estimated at 4.3 feddans. Average production per household was estimated at $418 \mathrm{~kg}$ and $166 \mathrm{~kg}$ for millet and sorghum, respectively. Productivity recorded was $209 \mathrm{~kg} / \mathrm{feddan}$ and $237 \mathrm{~kg} /$ feddan for millet and sorghum, respectively. The study showed that due to insecurity conflicts 152,000 of the producer households were displaced in the IDPs camps. The estimated losses due to displacement were amounted to 149,000 metric tons of millet and 83,000 metric tons of sorghum.

The empirical results of trade analysis indicate that there is a good chance for intra-regional trade to operate in SDS provided that trade barriers removed [1]. For implementation of agricultural plan in SDS, production of food stable crops must be shift to areas of high rainfall and high fertility in Naga'a and Gardud soils. In the drought-affected moisture stressed environments introduction of early maturing varieties of millet and sorghum, provision of extension services and adoption of rainwater harvesting techniques are the needed measures [2]. Southern Darfur State will never satisfy its need of grain unless social security prevails in areas of production and return of civil war displaced farmers to places of farming. Introduction of mechanized farming in the alluvial soils of high rainfall and high fertility (Naga'a and Gardud soils) is the only best alternative to satisfying the need of grain in SDS under the current access insecurity of smallholders to their far farms.
\end{abstract}

\section{Introduction}

Southern Darfur State (SDS), the area of the study, is situated in the western part of the Sudan. Traditional rain-fed is the main type of agriculture that provides livelihood for approximately $82 \%$ of the population. Millet and sorghum are the main stable food crops and groundnuts is the main cash crop $[3,4]$. The characteristics of this sub sector are that the farm size is small not exceeding 10 feddan per household, low yield per unit area; production is mainly for subsistence. Crop production is concentrated by insecurity of farm access in areas of the easily food grain cultivated Qoz and Atmur sandy soils.

\section{Methodology}

Household survey was employed to generate the quantitative data related to livelihood and food security. Both household and

group questionnaires were developed to collect the primary data. The stratified random sampling method was used to select respondents of the study [5]. The data of post-harvest surveys conducted in SDS was the main concern of the analysis for the study time span 1987-2007 [6].

\section{Results and Discussion}

The result of the study revealed that the main factors constraining production in SDS are insecurity which represents $30 \%$ [7], ineffective control of pests and diseases $20 \%$, poor genetic stock $20 \%$, inadequate amount of rainfall $14 \%$ and low fertility of Goz and Atmur soils 6\%, lack of extension service 6\% and financial inability $4 \%$. The small producers have limited access to credit and released technological knowledge. Total area planted per household 
was estimated at 4.3 feddan. Average production per household was estimated at $418 \mathrm{~kg}$ and $166 \mathrm{~kg}$ for millet and sorghum respectively. Productivity recorded was $209 \mathrm{~kg} /$ feddan and $237 \mathrm{~kg} /$ feddan for millet and sorghum respectively (Figure 1). The study showed that due to insecurity conflicts 152,000 of the producer households were displaced in the camps of SDS. Accordingly, the estimated losses, due to displacement, were amounted to 149000 metric tons of millet, 83000 metric tons of sorghum.

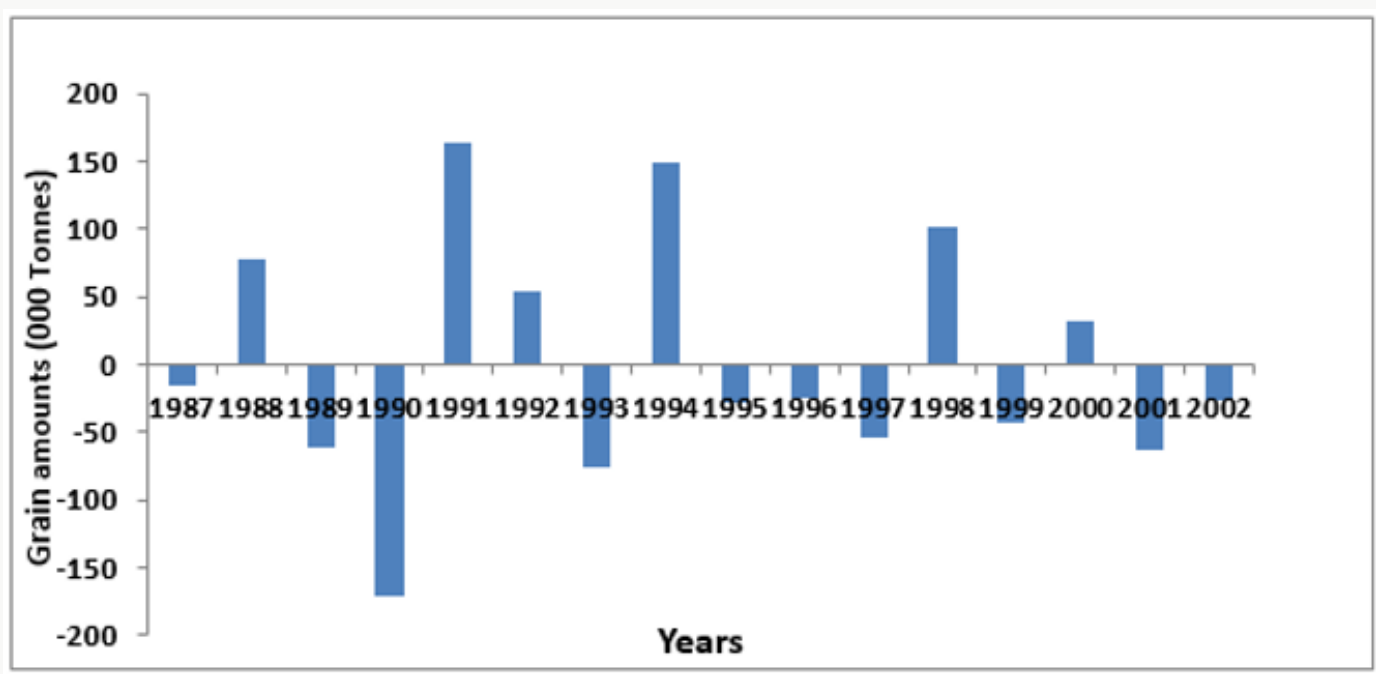

*Subsistence balance is the balance of grain produced and consumed in the State.

Figure 1: Subsistence balance in SDS during the period 1987-2002.

Table 1: Subsistence balance* in S D S during the period 1987-2002 (000 tones).

\begin{tabular}{|c|c|c|c|c|c|c|c|c|}
\hline Year & 1987 & 1988 & 1989 & 1990 & 1991 & 1992 & 1993 & 1994 \\
\hline Grain balance & -16 & 78 & -61 & -171 & 164 & 55 & -76 & 150 \\
\hline \multicolumn{9}{|l|}{ Continue: } \\
\hline Year & 1995 & 1996 & 1997 & 1998 & 1999 & 2000 & 2001 & 2002 \\
\hline Grain balance & -28 & -24 & -54 & 101 & -43 & 33 & -64 & -26 \\
\hline
\end{tabular}

Source: Post-harvest surveys in SDS during the period 1987-2002.

Table 2: Subsistence balance* in S D S during the period 2001-2007 (000 tones).

\begin{tabular}{|c|c|c|c|c|c|c|c|}
\hline Year & $\mathbf{2 0 0 1}$ & $\mathbf{2 0 0 2}$ & $\mathbf{2 0 0 3}$ & $\mathbf{2 0 0 4}$ & $\mathbf{2 0 0 5}$ & $\mathbf{2 0 0 6}$ & $\mathbf{2 0 0 7}$ \\
\hline Grain balance & -64 & -26 & -117 & -292 & -221 & -75 & -425 \\
\hline
\end{tabular}

Source: Post-harvest surveys in SDS during the period 2002-2007.

Before the war conflict, during the period 1987-2002, rainfall and other factors were considered to be the main reasons attributed to grain gap in SDS (Table 1). The situation was aggravated by insecurity problem since 2003 and it became the main reason attributed to grain gap in SDS during the period 2002-2007 as shown in Table 2 and Figure 2 below. As a result of successive grain gap, the prices of millet and sorghum became very high compared to those prices in the adjacent States of the country. The empirical results of trade analysis indicate that there is a good chance for intra-regional trade to operate in SDS provided that barriers could be removed. From the forgoing discussion an agricultural development plan is suggested. The most attractive plan to increase small holder agricultural productivity and production is through adoption of new technologies and opening new areas for production. For implementation of this plan production of food stable crops must be shift to areas of high rainfall and high fertility in Naga'a and Gardud soils. Guard soil is amounted to ten million feddan and Naga'a six million feddan. The soils are sand, clay loams and non-cracking clays, with weak surface structure and suffer from hard compacted surface sealing. They have a high potential for dry land farming if necessary, soil and water conservation and management practices are undertaken. Tillage operations are needed to break-up surface seal and massive sub-surface layers using mainly chisel and disc plough especially when combined with $10 \mathrm{~m}$ contour diking was found to be the most suitable surface management techniques for these soils [8]. Also, there is bad need 
for investment in infrastructure such as roads, bridges and water before any agricultural activities can start. In the drought-affected moisture stressed environments introduction of early maturing varieties of millet and sorghum, provision of extension services and adoption of rainwater harvesting techniques are the needed measures.

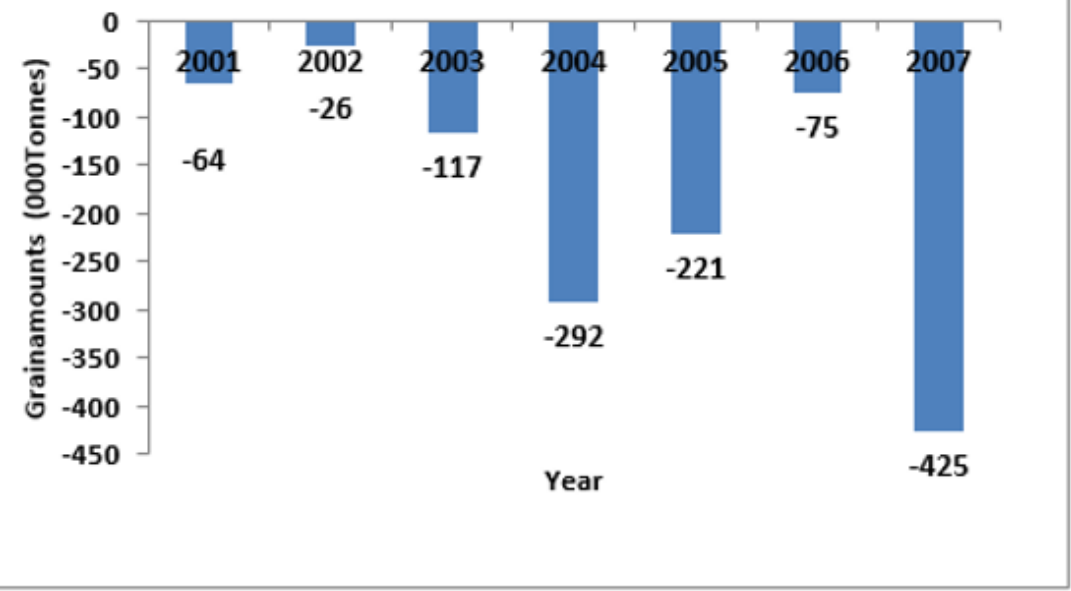

*Subsistence balance is the balance of grain produced and consumed in the State.

Figure 2: Grain balance in SDS during the period 2001-2007.

\section{Conclusion}

a) Southern Darfur State will never satisfy its needs of grain unless security prevails in areas of production and return of displaced farmers to place of farming.

b) Introduction of mechanized farming in the alluvial soils of high rainfall and high fertility (Naga'a and Gardud soils) is the best alternative to satisfying the increasing need of food grain in South Darfur State.

\section{References}

1. Central Ministry of Agriculture (1986) Strategy for Development of Rainfed Agriculture. Institutions and Finance Task Force. Khartoum, Sudan.

2. Clarke LJ (1997) Agricultural Mechanization Strategy Formulation: Concepts and Methodology and the Roles of the Private Sector and the Government. FAO, Rome, Italy.

3. Fadlalla B (2006) Darfur Joint Assessment Mission: A vision and priority program for post conflict development in Darfur.
4. Mohamed BA, Ahmed HA, Mohamed SM (2002) Socio-Economic impact of Introduction of Donkey Plough in Qoz Soil on Groundnut (Case Study of Southern State). Annual Report, Socio-Economic Research Program 2003/2004. Agricultural Research Corporation, Sudan.

5. Mohamed BA, Al Amin MA (2000) 1999's Diagnostic Survey in the Traditional Rain fed of Southern Darfur State. Annual Report, SocioEconomic Research Program 2000/2001. Agricultural Research Corporation, Sudan.

6. Omer MA (1994) Effect of Tillage and Contour Diking on Rainfall Water Harvesting and Sorghum Yield. Annual Report. El-Obeid Research Station 1994/95, Sudan, pp. 60-62.

7. Quin M, Willcocks T (1989) Sudan: Development of Crop Production on Naga'a and other Alluvial Soils in South Darfur. Development Division in Eastern Africa, ODA, UK, pp. 14-28.

8. State Ministry of Agriculture (1997-2005) Post-Harvest Assessment, Southern Darfur State, Sudan. Western Savannah Development Corporation (1986-1996). Post-Harvest Assessment, Southern Darfur State, Sudan.

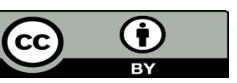

This work is licensed under Creative Commons Attribution 4.0 License

To Submit Your Article Click Here:

Submit Article
DOI: 10.32474/CIACR.2018.05.000211

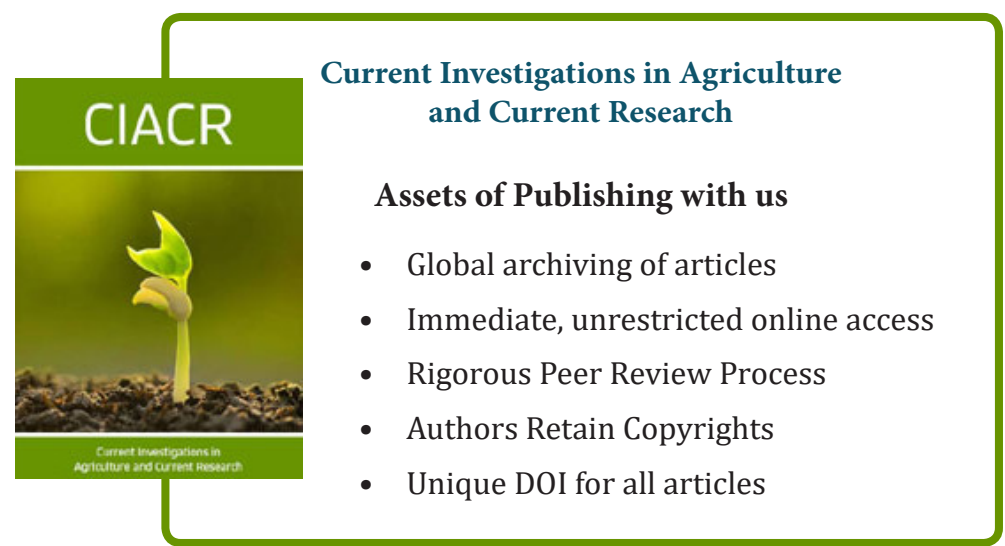

